\title{
Records of Cyrtocarcinus truncatus (Rathbun, 1906) (Decapoda: Xanthidae) from the Loyalty Islands, New Caledonia, and the Ryukyu Islands, Japan
}

Tohru Naruse, Mathilde Richer de Forges, Bertrand Richer de Forges, Daisuke Uyeno

\begin{abstract}
A rare xanthid crab species Cyrtocarcinus truncatus (Rathbun, 1906) is recorded from Ouvéa, Loyalty Islands, New Caledonia, and Ishigaki Island, Ryukyu Islands, Japan. This represents the first record of the species from outside Hawaii. Morphological features and its variations are described in detail.
\end{abstract}

LSID urn:1sid:zoobank.org:pub:14F92D49-B158-4B4A-A58F-2385635A1AFB

Key words: Range extension, intraspecific variation

\section{Introduction}

Cyrtocarcinus truncatus (Rathbun, 1906) is a relatively rare xanthid species. The species was first described based on a small female specimen from Hawaii. Subsequently Edmondson (1951) and Takeda (1979) recorded additional specimens from the Hawaiian Islands, and Lai et al. (2011) used a female specimen from $\mathrm{Ou}-$ véa, Loyalty Islands, New Caledonia, for a molecular phylogenetic study. This present study examines the specimen from Ouvéa as well as a recently collected female from Ishigaki Island, Ryukyu Islands, Japan, to report on the distribution, live coloration and morphological variation of this species.

Material examined are deposited in the Ryukyu University Museum, Fujukan (RUMF), University of the Ryukyus, Japan, and Muséum national d'Histoire naturelle, Paris (MNHN). Measurements are indicated as carapace length $(\mathrm{CL}) \times$ carapace width $(\mathrm{CW})$, in millimeters. Other abbreviations used in this paper are as follows: Mxp, third maxilliped; P2-5, second to fifth pereopods (first to fourth ambulatory legs). Alpha-numeric codes for carapace re- gions follow that of Dana (1852: 29).

$\square$ Species Account

Family Xanthidae MacLeay, 1838

Cyrtocarcinus $\mathrm{Ng} \&$ Chia, 1994

Cyrtocarcinus truncatus

(Rathbun, 1906)

[New Japanese name: Zumi-ougigani]

(Figs. 1-5)

?Harrovia truncata Rathbun, 1906: 886, pl. 14, text fig. 40; Edmondson, 1951: 217, figs. 21, 22.

Harrovia truncata - Flipse 1930: 80, 90 (no new record); Serène et al. 1958: 196, 199, figs. 7A (no new record); Serène 1968: 63 (no new record).

Glyptocarcinus truncatus — Takeda 1979: 68; Števčić et al. 1988: 1311 (no new record).

Cyrtocarcinus truncatus - Ng \& Chia 1994: 725, figs. 11-13; $\mathrm{Ng}$ et al. 2008: 196 (no new record); Lai et al. 2011: 415, fig. 9j, 440,442 .

Material examined. MNHN-IU-2014-20316 


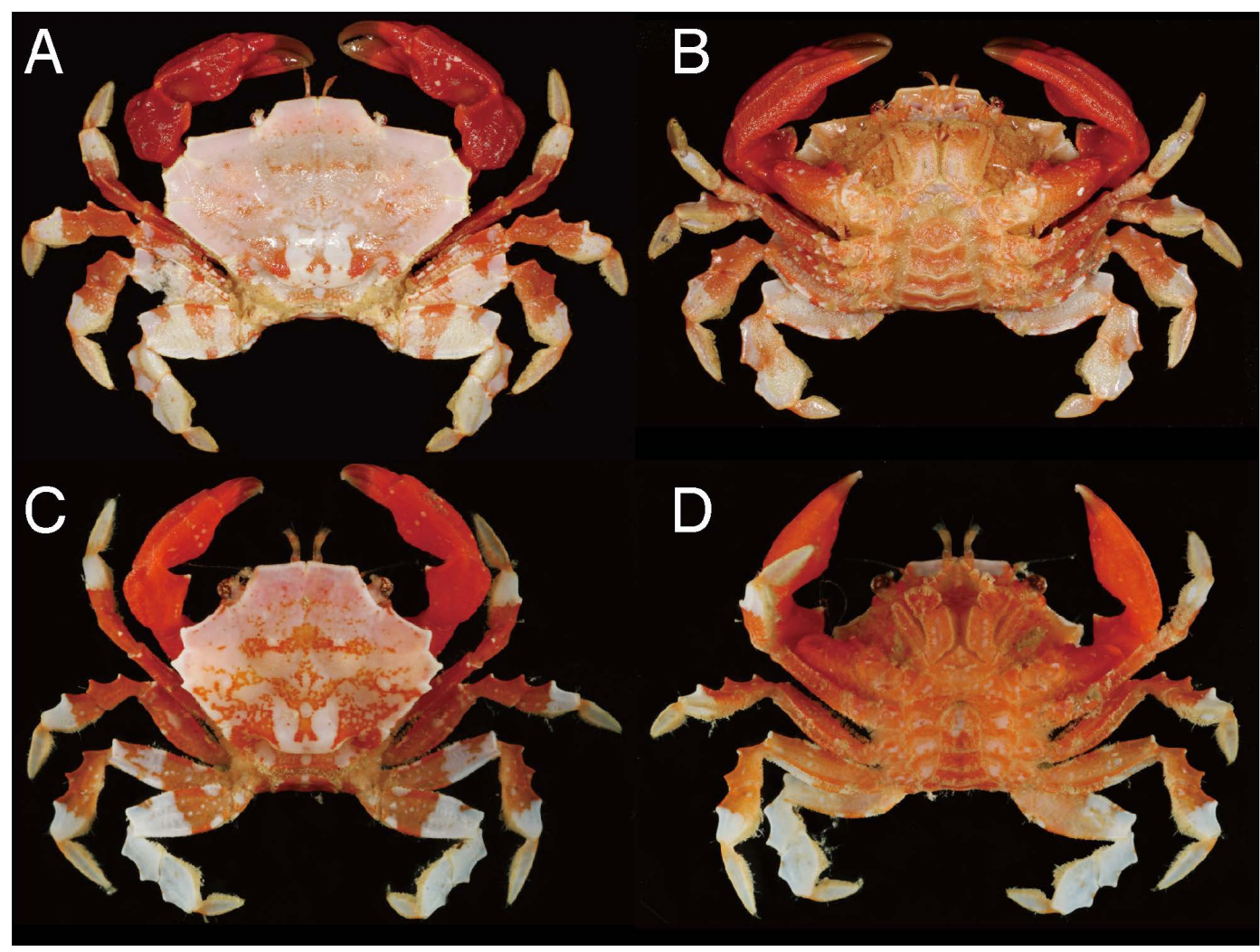

Fig. 1. Cyrtocarcinus truncatus (Rathbun, 1906). A, B, MNHN-IU-2014-20316, female, CW 29.0 mm; C, D, RUMF-ZC-4308, female, CW $8.0 \mathrm{~mm}$.

(ex. RUMF-ZC-1302), 1 female, $19.2 \times$ $29.0 \mathrm{~mm}$, Est de Mouly, Ouvéa, $20^{\circ} 43.025^{\prime} \mathrm{N}$ $166^{\circ} 24.710^{\prime} \mathrm{W},-10-13 \mathrm{~m}$, coll. D. Uyeno et al., 12 June 2009; RUMF-ZC-4308, 1 female, 6.2 $\times 8.0 \mathrm{~mm}$, Uganzaki, Ishigaki Island, Ryukyu Islands, Japan, $-10 \mathrm{~m}$, coll. Y. Akutsu \& K. Okuda, 8 June 2015.

Description. Carapace dorsal surface (Fig. $1 \mathrm{~A}, \mathrm{C})$ weakly convex on $2 \mathrm{M}, 5 \mathrm{~L}, 1 \mathrm{P}$, lateral regions thinly expanded, weakly upturned (Fig. 2B), 1P (cardiac region; Fig. 3D) produced posteriorly, bilobed, overhanging onto intestinal region, surfaces minutely granulated on convex regions; intestinal region low, flat, not forming plate-like structure. Front produced anteriorly, slightly inclined downward, frontal margin bilobed by weak fissure (Fig. 2A). Supraorbital margin short, with 2 short fissures, external orbital angle small, connected ventrally as low ridge. Infraorbital margin (Figs. 2A, $3 \mathrm{~A}$ ) incomplete, represented by two strong teeth, mesial one longer. Margin between external orbital angle and first epibranchial tooth well defined, strongly divergent posteriorly, second tooth placed closer to third than first tooth, most extended laterally, with 1 narrow fissure each between first and second, second and third teeth (Figs. 1A, C, 5). Posterolateral margin (Figs. 1A, 3D) almost straight, with 1 fissure on almost same level with lateral end of $1 \mathrm{P}$ protrusion, posterior end not confluent with posterior margin. Posterior margin broadly concave medially. Suborbital region (Fig. 2A) sparsely granulate, with 1 nodule posterolateral to orbit. Pterygostomial region divided into upper, lower portions by shallow and wide depression. Subhepatic region with 1 low ridge 


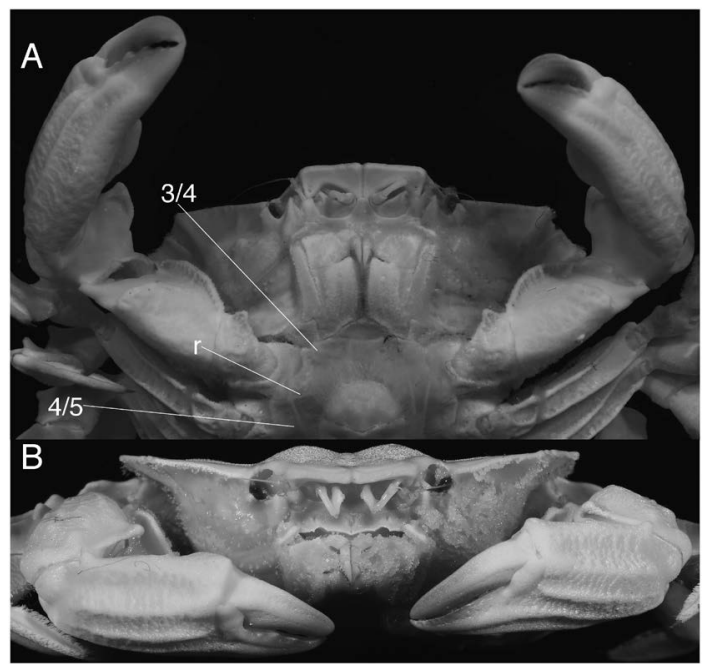

Fig. 2. Cyrtocarcinus truncatus (Rathbun, 1906). MNHNIU-2014-20316, female, CW $29.0 \mathrm{~mm}$.

A, cephalothorax, ventroanterior view; B, cephalothorax, anterior view. $3 / 4,4 / 5$, sutures between respective sternites; $r$, short oblique rim. lateral to orbit and below epibranchial tooth, with three oblique rows of granules from epimeral sulcus above cheliped base extended posteriorly along sulcus; sub-branchial channel present between posterolateral margin and epimeral sulcus (Fig. 3D). Ventral surface of carapace with distinct papilliform setae (Fig. 3A) on suborbital, pterygostomial, subhepatic regions, especially on convex portion, e.g. granules and more convex lower portions of subhepatic region, two protrusions of pterygostomial region, ridge below epibranchial teeth, 3 rows of subhepatic and side walls (Fig. 3B).

Eye (Figs. 1, 3A) small, base of stalk granulated, strongly constricted at base of cornea, with 1 spine on upper and outer portions of cornea each.

Antennular fossae (Fig. 2A) semicircular, basal article occupying slightly more than half

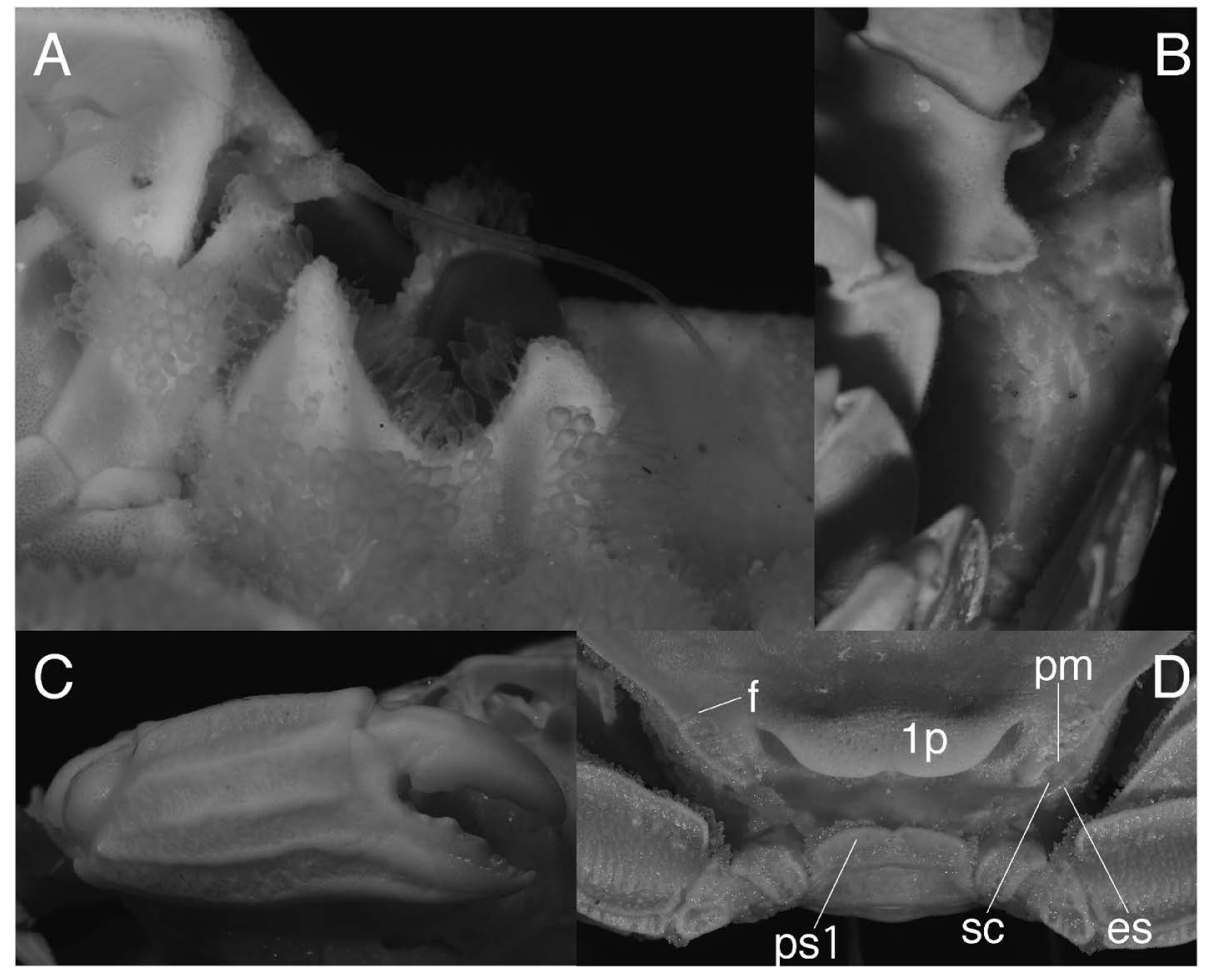

Fig. 3. Cyrtocarcinus truncatus (Rathbun, 1906). MNHN-IU-2014-20316, female, CW $29.0 \mathrm{~mm}$.

A, left orbit, ventroanterior view, with papilliform setae; B, left side wall of cephalothorax, ventrolateral view; C, right chela, outer view; D, carapace dorsopoterior view, showing overhanging cardiac region. 1p, cardiac region; es, epimeral sulcus; f, fissure; pm, posterolateral margin; ps1, pleonal somite 1; sc, sub-branchial channel. 
at posterolateral portions.

Basal antennal article (Figs. 2A, 3A) simple, rectangular, slightly oblique, flagellum long, exceeding orbit by its half-length.

Epistome (Fig. 2A) longitudinally long, with median and sublateral fissures, posterior margin weakly upturned medially produced, with sublateral semicircular concavities, lateral fissure started from sublateral portion of concavity.

Mxp3 (Fig. 2A) ischium subrectangular, outer surface granulated, with submedian sulcus, carpus quadrate, distolateral angle slightly produced laterally, granulated proximomesially, exopod with long flagellum, exceeding width of merus.

Chelipeds (Figs. 1, 2) almost symmetrical in females. Ischium with reticulate pattern on ventral surface, anterior surface with acute lobe subdistally. Merus (Figs. 1B, D, 2A) with semi-triangular cross-section, lower surface with reticulate pattern, one strong tooth distally, and another subdistally; posterior margin with one large tooth each subdistally and subproximally, subdistal one larger; anterior margin cristate, overhanging onto lower surface, upper surface convex medially. Carpus (Fig. 1) large, with strong inner angle, upper surface with reticulate pattern except for distolateral part.

Chela outer surface (Fig. 3C) with low 4 ridges and in-between reticulate patterns; palm about 2.5 times length of immovable finger, superiorly with 1 ridge that is connected from hinge with carpus, inner margin with longitudinal high protuberance medially, teeth on cutting edges, developed in margin, chela (right) with specialized molariform tooth on base of movable finger.

Ambulatory legs (Fig. 1) compressed, foliaceous, P2 and P3 about in same length, P5 shortest; merus posterior surface flanked by two ridges, anterior margin forming foliaceous simple rim; carpus outer margin with subproximal, subdistal lobes, subdistal larger; propodus with submedian tooth on outer margin, inner

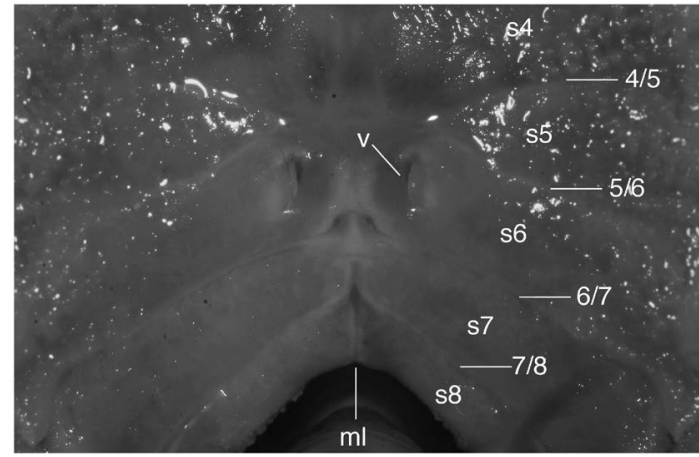

Fig. 4. Female thoracic sternum of Cyrtocarcinus truncatus (Rathbun, 1906), posteroventral view. MNHNIU-2014-20316, female, CW $29.0 \mathrm{~mm}$.

4/5-7/8, sutures between respective sternites; ml, median longitudinal line; s4-8, sternite 4-8, respectively; v, vulva.

surface slightly concave medially, flanked by dense mats of papilliform setae; dactylus widest subproximally, tapering distally, ending in chitinous claw, inner margin with dense mat of thick but soft simple setae; outer margin convex with setae, setation similar to that of inner margin, but shorter and thicker.

Pleon and telson all free, pleonal somite 1 with strong ridge subproximally, ridge bilobed, directed dorsally; somite 3 widest. Pleopods developed.

Thoracic sternite 2 and 3 demarcated by sinuous suture; thoracic sternites 3-6 granulate laterally; sternite 4 with a pair of short, oblique, granular ridges at lateral ends on proximal third; sutures 3/4 short, deep, 4/5 and 5/6 long, these sutures interrupted medially; suture 6/7 long, terminated mesially as a deep pit, barely separated from each side by a narrow longitudinal keel; suture 7/8 connected, posterior half of sternite 7 and 8 with median longitudinal line (Fig. 4). Vulva (Fig. 4) oblong, oblique, pushed to suture $5 / 6$ outwards, but not touching; membrane developed from lateral margin.

Distribution. Hawaiian Islands (Rathbun 1906; Edmondson 1951; Takeda 1979); Ouvéa, Loyalty Islands, New Caledonia; and Ishigaki 


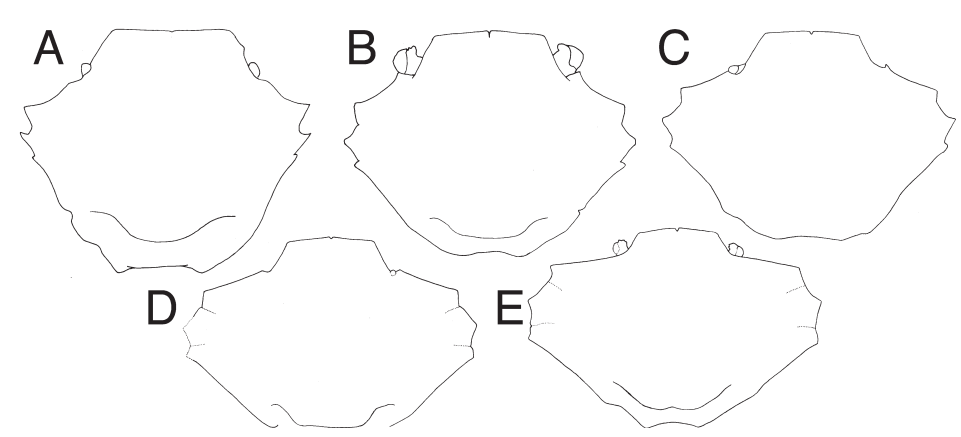

Fig. 5. Change in carapace outline of Cyrtocarcinus truncatus (Rathbun, 1906).

A, holotype, USNM 29804, male, CW 6.5 mm; B, RUMF-ZC-4308, female, CW 8.0 mm; C, BPBM S8566, male, CW 13.5 mm; D, BPBM S5632, male, CW 26.0 mm; E, MNHN-IU-2014-20316, female, CW $29.0 \mathrm{~mm}$. Outlines of A-D were traced from following references: A, Rathbun (1906: pl.14, fig 8); C, Ng \& Chia (1994: figs. 11A); D, Ng \& Chia (1994: figs. 12A).

Island, Ryukyu Islands, Japan (present study).

Coloration. Dorsal surface of the carapace with whitish ground colour and reddish mottled patterns. Chelipeds dark to bright red, distal half of cheliped fingers chocolate brown. Ambulatory legs of small individual (Fig. 1C, D) vermilion on $\mathrm{P} 2$ and $\mathrm{P} 3$ meri to proximal half of propodi, $\mathrm{P} 4$ proximal half of merus, whole carpus and proximal half of propodus, and P5 proximal half of merus; other parts whitish. Large individual (Fig. 1A, B) has mottled whitish patterns in $\mathrm{P} 2-5$ meri.

Edmondson (1951: 219) noted that "(c)olor of living specimens white, with the exception of the chelipeds which are bright red" and did not mentioned about vermilion patterns in ambulatory legs, but overall pattern is similar to what we observed in the present study.

Remarks. Cyrtocarcinus truncatus has only been recorded from Hawaiian Islands (Rathbun 1906; Edmondson 1951; Takeda 1979), but the present study found the species from Ouvéa, Loyalty Islands, New Caledonia, and Ishigaki Island, Ryukyu Islands, Japan.

Cyrtocarcinus truncatus appears to change its carapace outline in accordance with the growth (Fig. 5). Small individuals tend to have narrower carapace (e.g. holotype, CW $6.5 \mathrm{~mm}$, $\mathrm{CW} / \mathrm{CL}=1.18$, Fig. 5A, Rathbun 1906 pl.14 fig. 8). The lateral margins of the carapace become proportionally more expanded laterally along with the growth, and posteriorly divergent and slightly sinuous margins between the external orbital angle and first anterolateral tooth become more straight and almost horizontal in larger individuals (e.g. RUMFZC-1302, CW $29.0 \mathrm{~mm}, \mathrm{CW} / \mathrm{CL}=1.51$, Figs. 1A, 5E).

Ng \& Chia (1994) established the subfamily Antrocarcininae to accommodate Antrocarcinus Ng \& Chia, 1994 (monotypic), Cyrtocarcinus Ng \& Chia, 1994 (monotypic), and Glyptocarcinus Takeda, 1973 (2 species). In the context of discussion, they listed the following diagnostic characters: "the peculiar form of the interrupted posterolateral margin with the posterior sub-branchial channel, very swollen cardiac region which may overhang the deep cardio-intestinal groove, plate-like intestinal region, the fingers of the chelipeds being pigmented only at the tip and along the cutting edges, a sternite 4 with a transverse median ridge, elongate second antennal segment, and the male abdominal segments $3-5$ being immovable despite having all the sutures deep and distinct" and "the lateral clefts demarcating sternites 3 and 4 are very deep” (Ng \& Chia 1994: 703). Cyrtocarcinus truncatus, however, lacks neither convex nor plate-like intestinal region (Fig. 3D), and female sternite 4 possess- 
es a pair of oblique granular ridges laterally (Fig. 2A) instead of a transverse median ridge. Nevertheless C. truncatus still share all other diagnostic characters and is morphologically closest to other antrocarcinines.

Lai et al. (2011) tested systematics and classification of Xanthidae MacLeay, 1838, by phylogenetic analysis using four markers. The specimen of $C$. truncatus from Ouvéa (MNHN-IU-2014-20316) reported in this study was used in the analysis. Cyrtocarcinus truncatus formed a monotypic clade with Glyptocarcinus lophopus and G. politus, the only antrocarcinines examined in this study. This antrocarcinine clade is, however, grouped in "Eux 3", which also includes 17 species in 10 genera of Euxanthinae Alcock, 1898, and 4 species in 3 genera of Xanthidae MacLeay, 1838 (Lai et al. 2011: 429, fig. 1). Further study is needed for a better understanding of their relationships and classification.

\section{Acknowledgements}

The "Service de l'Environment de la Province Des îles Loyauté" in Wé, Lifou, who funded KIWA Consulting to perform the biodiversity survey of Ouvéa lagoon. We thank Yoshimichi Akutsu and Kazumi Okuda (Ishigaki Sensui-do) for providing a specimen from Ishigaki Island.

\section{$\square$ Literature Cited}

Dana, J. D., 1852. Crustacea. Part I.-United States Exploring Expedition during the Years 1838, 1839, 1840, 1841, 1842, under the Command of Charles Wilkes, U. S. N., 13: i-viii, 1-685; Atlas [1855], pp. 1-27, pls. 1-96.

Edmondson, C. H., 1951. Some Central Pacific crustaceans. Occasional Papers of the Bernice P. Bishop Museum, 20(13): 183-243.

Flipse, H. J., 1930. Decapoda F. (Decapoda Brachyura continued) Oxyrhyncha: Parthe- nopidae. Siboga Expéditie, 39(C2): 1-96.

Lai, J. C. Y., Mendoza, J. C. E., Guinot, D., Clark, P. F., \& Ng, P. K. L., 2011. Xanthidae MacLeay, 1838 (Decapoda: Brachyura: Xanthoidea) systematics: A multi-gene approach with support from adult and zoeal morphology. Zoologischer Anzeiger, 250: 407-448.

Ng, P. K. L., \& Chia, D. G. B., 1994. The genus Glyptocarcinus Takeda, 1973 with descriptions of a new subfamily, two new genera and two new species from New Caledonia (Crustacea: Decapoda: Brachyura: Xanthidae). Raffles Bulletin of Zoology, 42(3): 701-731.

Ng, P. K. L., Guinot, D., \& Davie, P. J. F., 2008. Systema Brachyurorum: Part I. An annotated checklist of extant brachyuran crabs of the world. Raffles Bulletin of Zoology, Supplement, 17: 1-286.

Rathbun, M. J., 1906. The Brachyura and Macrura of the Hawaiian Islands. Bulletin of the Bureau of Fisheries, 23(3): 827-930, pls. $1-24$.

Serène, R., 1968. The Brachyura of the Indo Pacific Region. In: Prodromus for a Check List of the Non-planctonic Marine Fauna of South East Asia. Special Publication of the Singapore National Academy of Science, No. 1. Pp. 33-120.

Serène, R., Tran, V. D., \& Nguyen, V. L., 1958, Eumedoninae du Viet-nam (Crustacea) (avec une bibliographie de la Sous-famille). Treubia, 24(2): 135-242, pls. 4-7.

Števcic, Z., Castro, P., \& Gore, R. H., 1988. Reestablishment of the family Eumedonidae Dana, 1853 (Crustacea: Decapoda: Brachyura). Journal of Natural History, 22: 13011324.

Takeda, M., 1979. Generic and specific validity of Glyptocarcinus lophopus Takeda (Crustacea, Brachyura). Proceedings of the Japanese Society of Systematic Zoology, 17: 6872 . 


\section{Addresses}

(TN) Tropical Biosphere Research Center, Iriomote Station, University of the Ryukyus, 870 Uehara, Taketomi, Okinawa 907-1541, Japan (naruse@lab.u-ryukyu.ac.jp)

(MRdF) Department of Conservation, Marine Science Advisor, 24 Wellesley Street, Auckland New Zealand

(BRdF) Correspondant du Muséum national d'Histoire naturelle, Paris, France

(DU) Graduate School of Engineering and Science, Kagoshima University, 1-21-35

Korimoto, Kagoshima 890-0065, Japan

\section{E-mail addresses}

$(\mathrm{TN})^{*}$ naruse@lab.u-ryukyu.ac.jp (MRdF)mdeforges@doc.govt.nz (BRdF) b.richerdeforges@gmail.com (DU) duyeno@sci.kagoshima-u.ac.jp *Corresponding author 